\title{
iPads in the classroom: trials in a technical college in Qatar
}

\author{
Cheri MacLeod \\ College of the North Atlantic - Qatar
}

\begin{abstract}
This paper describes a small research project undertaken in a technical college in Qatar on the use of iPads in the classroom. iPads were trialed for a semester each in mathematics and physics classes; students completed pre- and post-surveys. Classroom observations were carried out and interviews were conducted with both faculty $(\mathrm{N}=3)$ and students $(\mathrm{N}=19)$. Over $80 \%$ of students reported positively on the iPad as being "helpful" to "very helpful" for learning new things and course materials, for increasing their interaction with online course materials and getting course information and for exploring additional material related to course topics. Faculty perceptions of iPad use in class were also positive.
\end{abstract}

\section{Introduction}

Given the great and continually growing interest in the educational use of mobile technology, and iPads in particular, a classroom research project in the use of iPads in post-secondary classrooms was carried out at the College of the North Atlantic - Qatar (CNA-Q). The goals of this research were to gather information on student and faculty perceptions of iPad use; to determine if the iPad has the potential to enhance students' learning, connection to the course or communication with classmates; and to assess campus infrastructure and support capacity.

Student and faculty use of iPads was trialed for a semester each in two classes (one mathematics class and one physics class). Data collected included a pre-term survey for students; classroom observations; a follow-up survey for students; and interviews with students, faculty and the Campus Manager of IT Operations.

\section{Context}

The College of the North Atlantic - Qatar is the largest technical institution within Qatar and has approximately 2,400 full time students. Schools include Engineering Technology, Health Sciences, Business Studies, Information Technology and Language Studies, as well as Academics (communications, mathematics, sciences). In addition, the college has Technician Preparatory Program. CNA-Q also has a department of Corporate Training and Continuing Education, which offers short-term and evening programs.

CNA-Q is co-educational (approximately $60 \%$ male students, $40 \%$ female) with a student population made up of about $63 \%$ Qatari nationals. Another notable characteristic of the college is the importance of student sponsorship: over half the students are supported by local companies.

Mathematics and Physics, the courses in which the iPads were used for this trial, are both Academics courses and included males and females of many nationalities, all of whom were full-time students from the various schools. 
Currently, technology use within the college is heavily computer lab based (wired) with limited educational use of wireless mobile devices among instructors and students (e.g. mobile phones, laptops, netbooks) on campus. Technical and operational support was an important concern since the IT infrastructure within the college was created to support a PC system and has limited capacity to support wireless devices. Wireless access on the campus at the time of the trial was limited to 1,999 users at a time and this was an important consideration since classroom use of any technology depends on reliable and immediate access. Of course, the iPad is a wireless device and as such required access to the same wireless network access points that mobile phone users could connect to. One purpose of the research was to provide an opportunity for the department of IT Operations to informally review their ability to provide IT support and to identify possible user problems.

\section{Key concepts}

Since the iPad's launch in April 2010, proliferation of use has been swift. Initially many thought of the iPad as a large iPhone; however it is not only different from mobile phones, but also different from personal computers (Browne, 2011) and laptops (Pepperdine University, 2011).

The unique features of mobile devices, in particular of the iPad, create interesting possibilities for educational uses. Researchers report that important features include: user control over goals; ownership; fun; low cost; mobility; touch controls; long battery life; availability of useful and inexpensive applications; motion and speed sensors; and remote control of classroom computers (Johnson, 2011; Jones \& Issroff, 2007; Marmarelli \& Ringle, 2011; Sharples [Ed.], 2006; The iPad for Professors, 2011). 'Apps' (mobile device applications) are also important because most do not require a constant internet connection, launch faster than software on PCs and provide simplicity, instant gratification and relatively cheap alternatives to expensive software (The Economist, 2011).

The iPad has stimulated considerable interest in academia in the United States and this interest has spread internationally, including to the Middle East. Distribution programs and research or pilot projects have been initiated in colleges and universities in the United States and Australia including, among many others:

- Trinity College, University of Melbourne (Jennings et al., 2011)

- $\quad$ Nipissing University School of Business (Mang \& Wardley, 2012)

- $\quad$ Reed College (Marmarelli \& Ringle, 2011)

- Oklahoma State University (Halayka, 2011; Henrie, 2011; iPad Research Executive Summary, 2011),

- $\quad$ Seton Hill University (Gawelek et al., 2011;

- University of Notre Dame, (Chapla, 2011; Durbin, 2010; Early results from iPad pilot, 2010)

- Abilene Christian University (Roscorla, 2011; Shepherd \& Reeves; 2011; Baldridge \& McAdams, 2012)

Faculty and student response to the iPad in these studies has been positive. In the original Pepperdine University project, on which this research is modelled, nearly $75 \%$ of students reported the iPad as helpful or slightly helpful for sharing information in class (Pepperdine University, 2011). Participants in other studies have also recommended iPad use. In the Trinity College (University of Melbourne) pilot project over $80 \%$ of students and $76 \%$ of staff participants strongly recommended iPad use for other college students and staff (Jennings, Anderson, Dorset \& Mitchell, 2011). In the Nipissing University iPad trial $96 \%$ of students believed that tablets had enhanced their learning and $91 \%$ said they would like to use a tablet in the future. All faculty members in The Reed College iPad Study reported the iPad 
as extremely helpful for classroom preparation and very well suited to active classroom environments (Marmarelli \& Ringle, 2011) and 75 percent of students in the Oklahoma State University iPad pilot agreed or strongly agreed that the iPad enhanced the learning experience in their course (iPad Research Executive Summary, 2011).

Researchers have also reported on how iPads were used and on benefits of use. Seton Hill University's assessment of iPad use showed faculty and students endorsed the reduced need for paper handouts, readings and documents and used apps for a variety of tasks including writing, illustration and backchanneling (Gawelek et al., 2011). In the University of Notre-Dame pilot, participants reported numerous benefits of the device, including portability, ability to compile information in one place, ease of access, versatility and connectedness (Kristen, 2010). Key findings from Abilene Christian University's research into mobile learning included that the iPad increased student engagement, enabled collaborative learning, allowed potential student productivity and efficiency, and improved student technology competency (Shepherd \& Reeves; 2011).

In Qatar interest in iPads and mobile computing is high. iPad projects or trials have been undertaken at Georgetown University School of Foreign Service in Qatar (The Peninsula, 2013), Virginia Commonwealth University in Qatar and Texas A\&M University at Qatar (Thompson \& Fawley, 2010). Furthermore, Qatar University has taken an active role in the development of a number of iPhone/iPad applications (LisiSoft, 2013) as has the Qatar Computing Research Institute (Qatar Computing Research Institute, 2013).

Other mobile devices are also in use at the tertiary level in Qatar. At CNA-Q, Health Sciences practicum students use mobile devices with the Comptracker electronic competency tracking system (College of the North Atlantic - Qatar, 2012) and The University of Calgary - Qatar distributes smartphones for use in clinical courses (University of Calgary - Qatar, 2013).

Within the Middle East the United Arab Emirates (UAE) has significantly advanced the use of iPads. In 2012 iPads were distributed to first year students in three large educational intuitions in the United Arab Emirates in the largest systematic distribution in the world (Gitsaki et al, 2013).

At the end of the first academic year of iPad use in the Higher Colleges of Technology in the UAE Foundations students self-reported on their perception of improvement in their English language skills. Over 1,000 students agreed/ strongly agreed that their skills had improved in reading (82\% of respondents), grammar (81\%), vocabulary (87\%), listening $(80 \%)$ and writing $(80 \%)$. Faculty also perceived a positive impact on students' language skills (Gitsaki, 2013).

\section{Methods}

In recognition of the critical nature of reliable connectivity for the iPads the project was discussed with the manager of the CNA-Q Department of IT Operations prior to the start of the project. Possible service issues related to campus use and mobile device support were identified and communications were opened to allow IT Operations to informally review its ability to provide IT support. In addition, IT Operations agreed to provide priority Internet access for the iPads throughout the first term and to review issues with connectivity as necessary.

The initial research design for this project was based on a landmark research project undertaken at Pepperdine University, iPads in the Classroom (Chester, 2011; Chester et al., n.d.). Data collection in the CNA-Q research included: Pre-Term Technology Use Surveys for students (see Appendix A), classroom observations (see Appendix B: Classroom Observation Form), and Technology Follow-Up Surveys for students (see Appendix C). The pre-term technology use survey focused on students' technology 
ownership and usage. The classroom observation form provided a standard format used for note-taking on activities and numbers of students. The follow-up survey focused on students' technology use including iPad specific usage and their perceptions of the usefulness of iPads specifically and technology in general. Additionally, interviews with faculty, students and IT Operations management were conducted.

There was one major difference between this research and the Pepperdine model. The Pepperdine research design included comparisons of a class of students with iPads with a class of students without iPads. This was not possible at CNA-Q. In the term one mathematics course there was a full class of 'iPad' students but only one student research volunteer in the matched 'non-iPad' class. This made any comparisons invalid. In term two, for practical reasons, small physics classes were combined and there was only one physics class. This also eliminated the possibility of a comparison.

The procedures, surveys and loaner documents used in the Pepperdine University study (Chester, 2011; Chester et al., n.d.) were used as models for those used in this research. This was done to enable an extension of research done at Pepperdine and allow a valid comparison between the two studies. It is important to note however that the American and Qatari cultural contexts are quite different. The vast majority of students at CNA-Q use English as a foreign language so it was important to ensure that surveys and documents were easy for students to understand and appropriate to the local context. All written materials were carefully reviewed, edited for language and cultural appropriateness and trialed with students before use in the CNA-Q study. Changes made to accommodate the CNA-Q students required modification for clarity but no substantive changes in the types of questions asked or in research procedures.

The call for instructor participation in this project followed the Chicago Public Schools philosophy (iPad Integration Mini-Grant, 2010) by reaching out to Academics faculty interested in innovation, creative teaching and learning methods. There was no preference given to instructors with prior experience using particular types of computer devices.

Instructors were selected based on submissions of plans for iPad classroom use, course scheduling and availability during the length of the project. All students within the selected instructors' classes were invited to participate and to use an iPad over one academic term. Not all students, however, used a college provided iPad as some students already owned an iPad or iPad Mini and preferred to use their personal device.

During term one (mathematics) and term two (physics) identical research procedures were followed. Near the start of term the researcher visited classes to gain informed consent, distribute loaner agreements, distribute the prepared iPads and accessories, help with the set-up of college email on the device, and deliver the Pre-Term Technology Use Surveys to students. One difference in equipment between term one and term two was that in term two the physics instructor and his students were each issued with a stylus to assist with note-taking. Students who were absent for this initial visit came to the researcher's office at their convenience to pick up equipment and complete paperwork.

During the classroom distribution and orientation students appeared at ease with the iPads and had no difficulty getting their college email set up. Some students expressed excitement and were eager to share what they already knew, helping each other with set-up procedures. There was no 'general' orientation to the applications pre-installed on the iPads and instructor(s) provided instructions as needed in later classes.

Prior to the start of each term the researcher met with the instructors to clarify which applications should be installed and any support that might be needed. To make preparations for faculty and 
students as easy as possible the researcher and three student research assistants registered all loaned iPads under a common Apple account and completed all software application installations prior to iPad distribution. Students using their own devices installed applications themselves.

In the first term only five software applications were selected by the mathematics instructors (team teachers in the same course). Applications were chosen for communicating (Google+), presenting (Air Chalk Lite), screen-casting and desktop control (Doceri), document reading/annotation and storage (PDF Master) and a student response system (Socrative).

In the second term more software applications were requested by the physics instructor and were additionally installed for the following purposes: document reading and annotation (PDF Master); measuring acceleration (Acceleration); simple calculations (Calculator); iPad synchronization and presentations (Nearpod); note-taking (Notebook+); student screencasting and information sharing, (Showme); and document and link sharing (LiveBinders). About two weeks into term two, students reported that the free version of PDF Master was inadequate for their document storage needs. An assistant made a visit during class to upgrade the application to the paid version for all students, including those using their own devices; students absent on that day were asked to visit an on-campus office to get the upgrade.

Classroom observations were included in the research to provide evidence of what actually took place in the classroom learning environment, to allow confirmation of participant accounts and to clarify and allow greater understanding of reported participant perceptions. Observations also provided a starting point for discussions and general themes as in-depth interview questions were developed.

Throughout the term the researcher observed classes an average of once a week and took notes using a template that included basic information on time and location of the class, the start and end times of class phases, the number of students present in the class at the start and the end, and the class topics and activities. Observation notes also included how many students were grouped in activities and when and how iPads and other technologies were used during the class time (see Appendix 2, Classroom Observation Form).

At the end of each term all students completed the Technology Follow-Up Survey (see Appendix 3) to allow insight into students' use iPad and other technologies, their perceptions of the usefulness of the iPad and attitudes to technology. As well, post-term interviews were conducted with individual faculty and students. Student interviews were mostly individual but at students' request (for their convenience and comfort) two to three students were at times accommodated in one interview session.

\section{Findings}

Findings reported here are based on the Student Pre-term Survey results, instructor plans and classroom observations, the Student Technology Follow-Up Survey results, post-term interviews and device service and support.

\section{Student pre-term survey}

A total of 19 students participated in this research. This included all 10 students in the term one mathematics class and all 9 students in the term two physics class. No students were enrolled in both classes. Both classes were of mixed gender (12 males and 7 females overall) and mixed nationalities. Eight nationalities were represented amongst the students; although Qatari students formed the largest single group (8 students), nationalities included other Middle Easterners (Palestinian, Jordanian, Egyptian), as well as Sudanese, Filipino, Indian and Pakistani. Students' mean age was 23 years with a 
range from 19 to 37 years of age. About $80 \%$ of the students were in their first or second year at the college.

The Pre-Term Technology Use Survey provided information on the students prior to their exposure to classroom use of iPads. This survey included questions about students' personal background (given above), technology ownership and technology use. All 19 student-participants completed the survey.

About $80 \%$ of the students had wireless Internet access at home and reported owning several computing devices. Approximately $75 \%$ of students owned a desktop computer and just under $60 \%$ of students owned a tablet or similar mobile computing device. In fact, of the 19 students almost half (9) already owned an iPad. In addition, students owned other types of mobile devices (e.g. Ultrabook tablet/laptop, Galaxy Tab, Xtouch tablet). All but one student reported owning a laptop. The same number of students owned a mobile phone with Internet access. Many of the students owned multiple mobile phones, Blackberry being the most popular type, followed by Apple and Android based phones.

Students reported that their choice of technology device differed according to use. For general use students who owned both a desktop and a laptop reported that overall they used their laptops more than their desktops (15 out of 19 students). The device most used in students' daily lives was the mobile phone with internet access (14 out of 19 students). Respondents reported using smartphones for Internet access, social networking, texting, and email.

The devices most used for college were:

- $\quad$ mobile phone with internet access (11 out of 19 students)

- $\quad$ laptop (7 students)

- mobile computing device (3 students).

The popularity of the mobile phone for both daily life and college activities reflects the life style of most CNA-Q students. They carry their mobile phones with them at all times, both inside and outside of classes. The importance this student population gives to their connected mobile phones echoes the findings of a Cisco survey which found the smartphone to be young people's most desired computing device (Cisco, 2012; Gulf Times, 2012). Laptops and mobile computing devices are also portable and convenient for use in multiple locations so student ownership and acknowledgement of their importance is not surprising.

Students reported that they used technology daily for communication and obtaining information more than for entertainment or study. As already mentioned however, depending on use, their device of choice varied. Mobile phones were the most used device for communication and entertainment while laptops were the most used device for study and getting information (see Table 1 for details).

Table 1: Students' daily use of technology.

\begin{tabular}{|l|l|l|l|}
\hline \multicolumn{4}{|l|}{ Purpose of device use (\% of respondents): } \\
\hline Study & Communication & Entertainment & Getting Information \\
\hline $63 \%$ & $75 \%$ & $68 \%$ & $74 \%$ \\
\hline Device used most (\% of respondents): & For communication & For entertainment & For getting information \\
\hline For study & mobile phone (74\%) & $\begin{array}{l}\text { mobile phone (57\%) } \\
\text { laptop (43\%) }\end{array}$ & $\begin{array}{l}\text { laptop (45\%) } \\
\text { mobile phone (30\%) } \\
\text { laptop (57\%) } \\
\text { desktop (36\%) }\end{array}$ \\
\hline
\end{tabular}

McLeod, C. (2015). iPads in the classroom: trials in a technical college in Qatar. Learning and Teaching in 
Note: Some respondents identified more than one device.

As for students' ratings of their ability to use technology, most students rated themselves as intermediate to expert technology users (3 'expert', 12 'advanced', 3 'intermediate' and 1 at 'basic' level). Students generally exhibited attachment to toward the use of technology in that:

- they felt able to accomplish more in their student life because of technology (63\% of respondents)

- $\quad$ they either agreed or strongly agreed they felt unhappy if they did not use technology for a week (58\% of respondents).

\section{Instructor plans and classroom observations}

Classroom observations revealed different patterns of iPad use (a) between mathematics and physics courses and (b) between instructor plans for iPad use and actual use. Other technologies used in classes included: hand held calculators, an Electronic White Board, LCD projectors, a writable tablet (at times paired with a microphone), and desktop computers. Observations occurred once per week for the term.

\section{Mathematics}

In general, students' main classroom use of the iPad in the mathematics course was self-initiated to access email and course documents and the instructors' main use was for presentation and screencasting.

The mathematics instructors had previously had their classes scheduled in standard classrooms as opposed to computer labs and they made plans for piloting use of iPads in their course as a means of providing access to technology and the internet. Classes were actually scheduled in a room with an electronic whiteboard that also contained desktop computers (at the back of the room). This technology-rich venue meant instructors' planned use for the iPads and their actual use differed considerably.

Prior to the course start, team-teachers in the mathematics course planned use of iPads as a way to provide access to course materials using an electronic textbook, screencasts and videos, questions, online quizzes and practice examples. A web-based online quiz tool was identified as a key review and quizzing instrument (quizzes contributed to the course mark). Socrative was planned for use as an inclass questioning and audience response tool (for informal assessment with no marks attached). Wolfram Alpha (search engine and calculator) and Educreate (screen-caster and video sharing) were also identified for use.

In reality, iPads were used less than planned. Indeed, at times the iPads were unnecessary and the desktop computers were better suited to some tasks than the smaller mobile computing devices. For example, the desktop computers rather than the iPads were used to complete all the online quizzes and exercises (labs) that included calculations in Excel spreadsheets.

At the start of the term there were some challenges to planned iPad use. This related to accessing the electronic textbook (problems related to publisher access, not connectivity or device) and meant that plans to use the iPads to access the e-text directly were initially problematic. Printouts were used temporarily and then pdf documents sent by email as alternatives. Students used the iPads at their desks to access email for general communication, classroom assignments and pdfs of e-text materials as needed.

Mathematics instructors most often used the iPad for presenting (drawing and making calculations on the touch screen) and screencasting. Doceri was used regularly by instructors as a 'whiteboard type' 
application for classroom presentations and screencasting (screencasts were later posted on YouTube for students to review independently).

Although it was unanticipated during planning for iPad use, the mathematics instructors also used other technology including an 'electronic whiteboard' (used to display a calculator, calculations, the etextbook and documents) and hand-held calculators, as well as weekly use of desktop computers. An additional touch screen and microphone were also brought into a few classes for screencasting purposes.

\section{Physics}

Prior to the course start the physics instructor planned the use of iPads primarily as an informal assessment and discussion tool, using a student response system application, as well as for electronic materials distribution and note-taking.

The audience response system iPad app was used often in the class. Students were provided with thought-provoking questions or calculations (in multiple choice format), asked to discuss what they thought was the answer and to 'vote' on it. Sometimes this was done as a review and at other times to allow discussions that revealed common misconceptions.

As well, in every observed class (one class per week) the physics instructor projected (from the iPad) previously emailed electronic copies of exercises and class materials. Documents were in pdf format and the instructor projected his iPad screen while reading and taking notes, drawing graphs, making calculations and annotating documents. Students had the same application and regularly used it in class for annotation and note-taking as they followed the instructor's lesson. As noted earlier, a stylus was available to all participants in this course to make note-taking easier.

iPad use in the physics course was regular, with both the instructor and the students making use of the iPads in every observed class. iPad uses included: reading, projection and annotation on pdf documents (PDF Master); document sharing and distribution; student response (Socrative) and discussion.

\section{Reflection}

Plans for technology use are influenced by the classroom learning environment. As referred to earlier, in the mathematics class the need for iPads was reduced because the standard classroom was changed to a room that already included personal computers and additional technology. This room change was unanticipated, and the iPads were not the essential additions to this environment that they would have been in a less technology-rich learning environment. Students still used the tablets, but not for all the uses originally planned.

In the physics classroom there were no desktop computers available. The instructor used the iPads as planned to display (by projector) class notes and annotate them. Students used the tablets to communicate with the instructor, to view notes and to annotate notes during class. The instructor's ideas about this came out in the interview later when he reported feeling he could have expanded on the value and variety of use and improved on the format of the notes he provided.

Clearly, the use of a mobile device is influenced by the environment and the availability of other technology. A tablet is not a replacement for a desktop computer or for a powerful scientific calculator: technology users, both instructors and students, selected amongst the technologies available to them for different tasks. 


\section{Student technology follow-up survey}

In the Technology Follow-Up Survey all students were asked about their attitudes to technology as well as their actual use of technology during and outside of class. This included use of iPads and other computing devices (laptops, mobile phones, calculators, tablets or mobile computing devices and desktop computers).

The students in this study demonstrated a very positive attitude to technology:

- $100 \%$ of students felt they can do more in their student life because of technology

- $\quad 94 \%$ of students said that technology made their life easier

- $\quad 76 \%$ of students rated themselves as expert or advanced in the technologies they use

- $\quad 52 \%$ of students said they felt unhappy if they did not use technology for a week.

Student responses also reflected positive attitudes to the iPad. In general, over $80 \%$ of students indicated that they found the iPad helpful. More specifically, students described the iPad as "helpful" to "very helpful" for:

- $\quad$ learning new things (88\%)

- $\quad$ learning course materials (82\%)

- $\quad$ increasing interaction with online course materials (83\%)

- $\quad$ getting course information (82\%)

- $\quad$ exploring additional material related to course topics (82\%)

- $\quad$ sharing information with others in the class (88\%)

- $\quad$ interacting with other students (77\%)

- $\quad$ use during group work (65\%)

Students reported that during classes they used the iPads in $50 \%-90 \%$ of class periods, in order of frequency, for: reading; showing information to classmates; taking notes or researching on the Internet; doing homework or quizzes; and for non-course-related activities.

Outside the class students reported slightly lower iPad usage overall. The main uses of the iPads were similar to classroom use but, when compared to in-class use, showed a reduction in use for showing information to classmates and a small increase in use for non-course-related activities. This seems logical considering students might no longer be on campus and were also free to use their time for personal activities.

Student responses showed a variety of use of iPad applications. The most used apps were Google+, Socrative, Doceri, PDF Master and a calculator. Some differences in student usage patterns between mathematics and physics classes followed the patterns set by the course instructors' selection of apps. Usage patterns may have been influenced by availability (apps were already available and required no installation), familiarity (students became familiar with the apps during class and continued to use them rather than search for other apps) and/or instructor influence (introduction of the apps by instructors).

In terms of specific app use, mathematics students used Doceri more frequently and physics students used Socrative and PDF Master more frequently (applications chosen by instructors and sometimes used under instructor direction). Google+ and the calculator were used about equally by mathematics and 
physics students. Aside from the pre-installed (instructor selected) iPad applications students mentioned they also used Facebook, the calendar and Safari browser.

To provide insight into iPad limitations and any possible challenges faced during the research, students were asked to give examples of a time or situation when the iPads were not helpful to them. Examples provided highlighted the time needed to become familiar with applications, inability to open Flashbased objects and the need to charge the battery. Although not specific to the iPads as a device but to iPad use, one student stated that he did not like to do online tests because he could not go back and change his answers. He also did not like using electronic documents because he could write on paper faster and flip through his paper notes more quickly. Aside from physical speed, this could be because of his level of familiarity with the iPad or comfort with technology. As well, the same student suggested slow connections sometimes meant an app might not work.

Although this research focused primarily on use of the iPad, this was not the only device used during classes. It was unanticipated that one classroom would contain computers and additional technology; and other devices were reported as useful by $83 \%$ of students. Calculators were the most often used additional device in class, particularly in mathematics, although students also used mobile phones, desktop computers, laptops and other mobile devices. The most common uses for additional devices were for researching on the Internet and doing homework and quizzes. These were followed by reading and showing information to classmates.

Amongst all additional devices, outside of classes the mobile phone was the most commonly used. This was followed, in decreasing preference, by calculators and laptops (almost equal), desktops and then other mobile computing devices. As with the iPad, the most common use was reading; this was followed by researching on the Internet and doing homework and quizzes.

Although unanticipated in the research and teaching plans, the effect of the other technology could not be ignored because it impacted on iPad use. It seems clear that an iPad was not always the device of choice during class as the other devices that students used offered services also supported by iPads (Internet research, doing homework, quiz completion, reading).

\section{Post-term interviews}

Post-term interviews included questions about actual use of the iPads and iPad applications as well as the perceived usefulness and perceived ease of use (this relates to previous research devoted to The Technology Acceptance Model (Davis, 1989).

All instructors and students who were interviewed recommended the future use of iPads. This is interesting because plans for and actual use of the iPads varied and because the amount of use was different in mathematics and physics classes. This positive recommendation may be because the iPad's usefulness and ease of use were perceived as high by most of the research participants, regardless of how much the iPads were actually used.

\section{Instructors}

In the interviews at the end of the term, the two mathematics instructors gave recommendations for iPad use in future. Things they liked about the iPads included ease of use for students, reduction of paper that the use of electronic documents allowed, the immediate access to email, and the projection and screencasting that the Doceri application allowed. Despite their recommendation for future use, both instructors indicated that they had been unable to carry out all their plans and that their expectations of iPad use had not been fully met. They attributed this in part to the late arrival of the 
iPads (in the third week of classes due to a delay in the delivery of the equipment) and to the desktop computers in their classroom that made use of a mobile computing device less essential than would be the case in a standard classroom. They both had high hopes that the iPads would have a beneficial effect on the class but according to one instructor, the experience was 'underwhelming' and this certainly may have been due to the technology-rich learning environment.

When interviewed, the physics instructor, like the mathematics instructors, recommended use of iPads in future. He did, however, note that if using iPads again in his course he would make some changes in his practices such as reformatting his notes to make them easier to annotate and reducing use of email for communication with students by using a website or online repository (e.g. Facebook, Livebinder or an LMS such as Desire2Learn). The instructor reported that he felt he met his original goal of using the iPads (and Socrative) to encourage discussion and critical thinking and as a student response system. He was also satisfied overall with the usefulness of the iPads to reduce the use of paper, project documents, distribute materials, and to take and keep notes organized. He reviewed but did not use all of the iPads applications that were installed.

\section{Students}

Students in both courses found iPads useful for a variety of purposes and recommended use of iPads in future. All students in the mathematics course recommended use of iPads and reported that they found them useful to very useful for email, viewing the e-textbook and documents, accessing the Internet, and doing online quizzes. All the physics students who were interviewed also said they found the iPad useful to very useful. They reported that they used the iPads for easy (anytime, anywhere) access to email and the Internet, general study, reading documents, taking and keeping their notes organized and for playing games. One student said he liked the iPad but he still wanted some documents in paper format.

\section{Device service and support}

After the completion of the iPad research project the researcher discussed the project with the manager of the Department of IT Operations. No service issues related to connectivity, campus use or mobile device support were identified during the project by students, faculty or by the Department of IT Operations.

\section{Conclusions}

The three goals of this research were 1) to gather information on student and faculty perceptions of iPad use, 2) to determine if the iPad has the potential to enhance students' learning, connection to the course or communication with classmates and 3) to assess campus infrastructure and support capacity. These goals are discussed below.

1) Both faculty and students perceived utilizing iPads as valuable and useful. The specifics of what iPads were perceived as useful for is explained below.

2) iPads do have the potential to enhance students learning. Faculty and student responses suggest that iPads were helpful to very helpful for learning, connecting to the course and communicating with classmates. This clearly relates to the value of increasing student access to mobile computing technology in both the CNA-Q and the national college classroom.

Student perceptions were clear. About $80 \%$ of CNA-Q student participants reported the iPads as helpful to very helpful in general. Rates were higher for more specific uses such as learning new things (88\%) and sharing information with others in the class (88\%). Some $77 \%$ to $83 \%$ of students reported iPads as 
helpful to very helpful for learning course materials, increasing interaction with online course materials, getting course information, exploring additional material related to course topics, and interacting with other students. As well, all faculty in the CNA-Q study recommended the use of iPads in the future, with some personal qualifications based on how they felt about meeting their own goals during this project.

Approval ratings for iPad use amongst CNA-Q students and faculty participants were equivalent to or higher compared to results reported by other educational institutions that have completed iPad pilot projects or started use (as mentioned previously at Pepperdine University and in the literature review). The students in the CNA-Q study reported very positively on learning. This also follows student perceptions about improved learning reported in other studies. Clearly, students and instructors see value in iPad use.

A mobile phone or tablet such as the iPad is convenient to carry to class but despite portability and usefulness, small mobile devices have limitations and are not the first choice for all tasks. Some tasks are not suited to a small device. It is important to remember that for working in large spreadsheets, reading or producing long documents a laptop or desktop with a larger screen is sometimes more appropriate.

In addition to the task, the environment is important when selecting which technology to use. In a technology-rich environment such as a computer lab an iPad may not be the first choice. In a standard classroom (with no desktop computers) an iPad with wireless capacity offers the opportunity to communicate via email or instant message, share files, connect and research on the Internet, view and annotate on electronic class notes and access to special applications suited to the course. Participants in this study chose suitable technologies from those available within their specific, and unequally equipped, classroom learning environments.

Specific to the iPad, limitations mentioned by CNA-Q students were few. These related to the time needed to learn how to use applications, a lack of support for Flash-based objects and the need to charge the battery.

In terms of cost and portability, for the student or institution investing in a personal computing device for educational use, a tablet is both less expensive and more portable than larger devices. It is unclear how important the institutional provision of a mobile device is in Qatar. Internet access is high with Qatar 10th in the world on the UN Internet user list (United Nations, 2013). Most young people in Qatar already have a smartphone (Gulf Times, 2012; Cisco, 2012) and own or have access to multiple computing devices. It might be superfluous to require students to purchase and use a mandated mobile device such as an iPad when they already own a self-selected mobile computing device of some kind.

Recommendations for educators in the Gulf are at both institutional and personal levels. It is recommended that institutions seek ways to provide students and faculty with reliable and ubiquitous access to computing technology and to support student use of technology in the classroom. This may also require investigation of what kind of mobile device or policy best suits their context. Although campus-wide distribution of devices has great appeal it is not the only option. In contexts where students already own (multiple) devices, a bring-your-own-device (BYOD) policy (also called bring-yourown-technology, BYOT) provides an alternative to institutional deployment of mobile computing devices; although BYOD/BYOT still require institutional investment in infrastructure to support device use.

Additionally, it should be noted that a tablet (such as an iPad) does not replace a personal computer. Coursework such as the preparation of complex presentations, long reports or essays or use of spreadsheets and special software are better suited to a personal computer. Also, because the 
availability of technology influences the choice of device, it is important to plan carefully how and where mobile devices are most useful and truly add value. Less value is added when an iPad is provided in an already technology-rich learning environment such as a computer lab compared to a standard classroom.

On a personal level, educators are encouraged to improve their understanding and use of institutionally provided and personal mobile computing devices. This should include incorporating the use of iPads or other mobile devices in teaching and learning practices; planning for meaningful and regular use; attention to the context and tasks for which the device will be used; and openness to student suggestions about valuable uses and applications.

Finally, this project allowed an assessment of CNA-Q campus infrastructure and support capacity for iPad use. No problems in connectivity or conflicts were reported by students, faculty or the Department of IT Operations. This small group of users provided a limited preview of possible challenges with mobile device deployment across the CNA-Q campus but campus-wide deployment of mobile computing devices will still require additional hardware for device management as well as appropriate security measures, capacity building and policy development. This is now underway and the college community is deliberating on the future direction of mobile computing on campus.

\section{References}

Baldridge, S. \& McAdams, A. (2012). Remote teaching: Using mobile devices to teach outside of classroom walls. Retrieved September 28, 2013 from http://www.acu.edu/technology/mobilelearning/documents/research/baldridge/baldridge-mlpaper-11-12.pdf

Browne, B. (2011, August 5). Five Lessons from a Year of Tablet UX Research. UX Magazine. Defining and Informing the Complex Field of User Experience (UX). Retrieved January 16, 2012, from http://uxmag.com/articles/five-lessons-from-a-year-of-tablet-ux-research

Chapla, S. (2011, January 21). Study results: Students benefit from iPads in the classroom. University of Notre Dame. Notre Dame News. Retrieved February 7, 2012, from http://newsinfo.nd.edu/news/18178-study-results-students-benefit-from-ipads-in-the-classroom/

Chester, T. (2011, June 30). iPad Research Study. Technology and Learning. Pepperdine Community. Retrieved November 1, 2011, from http://community.pepperdine.edu/it/tools/ipad/research/

Chester, T., Hoover, D., \& Valencia, J. (n.d.). iPad Research Study Methodology. Pepperdine Community. Retrieved November 15, 2011, from http://community.pepperdine.edu/it/tools/ipad/research/method.htm

Cisco (2012). Connected world technology report. Retrieved December 29, 2012 from http://www.cisco.com/en/US/netsol/ns1120/index.html

College of the North Atlantic-Qatar. (2012). CNA-Q, School Of Health Sciences initiates the comptracker system. Retrieved October 19, 2013 from https://www.cnaqatar.com/HSPreceptor/Pages/ComptrackerProject.aspx

Davis, F. D. (1989). "Perceived usefulness, perceived ease of use, and user acceptance of information technology", MIS Quarterly 13(3): 319-340 
Durbin, K. (2010, November 12). iPad receives rave reviews. The Observer - University of Notre Dame and Saint Mary's College. Retrieved February 7, 2012, from

http://www.ndsmcobserver.com/news/ipad-receives-rave-reviews-1.1773423\#.TzDolMUs1BI

Early results from iPad pilot at University of Notre Dame. (2010, September 13). The CITE. Retrieved February 7, 2012, from http://thecite.blogspot.com/2010/09/early-results-from-ipad-pilot-at.html

Gawelek, M. A., Spataro, M., \& Komarny, P. (2011). Mobile Perspectives: On iPads - Why Mobile? EDUCAUSE Review, 46(2). Retrieved January 25, 2012, from http://www.educause.edu/EDUCAUSE+Review/EDUCAUSEReviewMagazineVolume46/iMobilePerspe ctivesOniPadsibrW/226163

Gitsaki, C., Robby, M.A., Priest, T., Hamdan, K. \& Ben-Chabane, Y. (2013). A research agenda for the UAE iPad Initiative. Learning and Teaching in Higher Education: Gulf Perspectives, 10 (2).

http://lthe.zu.ac.ae

Gulf Times. (2012, December 29). Report: youths prefer smartphones over PCs. Gulf Times, p. A2.

Halayka, J. (2011, May 4). iPad has Positive Impact on Academics in Oklahoma. iPad News, Reviews, Apps, Accessories, and Tips in Pad Gadget. Retrieved February 6, 2012, from http://www.padgadget.com/2011/05/04/ipad-has-positive-impact-on-academics-in-oklahoma/

Henrie, N. (2011, May 13). OSU study finds Apple's ${ }^{T M}$ powerful iPad decreases expenses, increases productivity. Students in Medicine for Resources in Technology. Retrieved February 6, 2012, from http://smrt.posterous.com/osu-study-finds-apples-powerful-ipad-decrease

iPad Integration Mini-Grant, Fall 2010 (n.d.). TextEdu. Retrieved January 20, 2011, from http://textedu.com/2012/02/ipad-integration-mini-grant-fall-2010/

iPad Research Executive Summary (2011, May 2). iPad study released by Oklahoma State University. Retrieved January 25, 2012, from https://news.okstate.edu/press-releases/929-ipad-study-releasedby-oklahoma-state-university

Jennings, G., Anderson, T., Dorset, M., \& Mitchell, J. (2011, October 24). Trinity College iPad Program, Research and evaluation: A work in progress. Trinity College iPad Program. Retrieved February 7, 2012, from http://ipadpilot.wordpress.com/

Johnson, B. (2011, October 31). Teaching and Learning: Using iPads in the Classroom. Edutopia. Retrieved December 6, 2011, from http://www.edutopia.org/blog/ipad-teaching-learning-apps-benjohnson

Jones, A., \& Issroff, K. (2007). Motivation and mobile devices: exploring the role of appropriation and coping strategies. Research in Learning Technology, 15(3), 247-258. Retrieved January 19, 2011, from http://journals.sfu.ca/coaction/index.php/rlt/article/download/.../12641

Kristen, D. (2010, November 12). iPad receives rave reviews. The Observer - University of Notre Dame and Saint Mary's College. Retrieved February 7, 2012, from

http://www.ndsmcobserver.com/news/ipad-receives-rave-reviews-1.1773423\#.TzDnycUs1Bk

LisiSoft (2013). LisiSoft iPadiPhone apps. Retrieved October 19, 2013from

http://appfinder.lisisoft.com/ipad-iphone-apps/qatar-university-qatar.html?cat=navigation

McLeod, C. (2015). iPads in the classroom: trials in a technical college in Qatar. Learning and Teaching in 
Mang, C. F., \& Wardley, L. J. (2012). Effective adoption of tablets in post-secondary education: recommendations bases on a trial of iPads in university classes. Journals of Information Technology Education: Innovations in Practice, 11, 301-317. Retrieved from http://www.jite.org/documents/Vol11/JITEv11IIPp301-317Mang1138.pdf

Marmarelli, T., \& Ringle, M. (2011). The Reed College iPad Study Portland. Faculty iPad Reports. Retrieved November 17, 2011, from http://web.reed.edu/cis/about/ipad_pilot/Faculty_iPad_Reports_April2011.pdf

Pepperdine University (2011). iPad Study Results. Retrieved November 1, 2011, from http://community.pepperdine.edu/it/tools/ipad/research/results.htm

Qatar Computing Research Institute. (2013). Arabic language technologies: Projects and demos. Retrieved October 19, 2013 from http://www.qcri.org.qa/our-research/arabic-languagetechnologies/arabic-language-technologies-projects

Roscorla, T. (2011, January 20). E-readers, E-books Represent Future for Community College. Converge Magazine: Technology in Education. Retrieved February 6, 2012, from http://www.convergemag.com/classtech/E-readers-E-books-Represent-Future-for-CommunityCollege.html

Sharples, M. (Ed.) (2006). Big Issues in Mobile Learning: Report of a workshop by the Kaleidoscope Network of Excellence Mobile Learning Initiative. Nottingham: University of Nottingham http://mlearning.noe-kaleidoscope.org/repository/Biglssues.pdf

Shepherd, I. \& Reeves, B. (2011, March 1). ipad or ifad? realities of a paperless classroom. Retrieved September 28, 2013 from http://www.acu.edu/technology/mobilelearning/documents/research/ipad-or-ifad.pdf

The Economist (2011, October 8). Apps on tap. The Economist - World News, Politics, Economics, Business \& Finance. Retrieved January 16, 2012, from http://www.economist.com/node/21530920?fsrc=scn\%2Ftw\%2Fte\%2Far\%2Fappsontap

The iPad for Professors: evaluating a productivity tool after one year (2011, March 27). The Chronicle of Higher Education. Retrieved January 19, 2012, from https://chronicle.com/article/The-iPad-forProfessors-/126885/

The Peninsula. (2013, April 03). Learning goes hi-tech: Tapping into technology to enhance learning. The Peninsula. Retrieved October 19, 2013 from http://thepeninsulaqatar.com/cover-plus/231624learning-goes-hi-tech-tapping-into-technology-to-enhance-learning.html

Thompson, C. \& Fawley, N. (2012, November). ipad applications in learning: Contrasting views from art and engineering. Technology In Higher Education Conference, Doha. Retrieved October 19, 2013 from http://technology.qatar.tamu.edu/2359.aspx

United Nations. The Broadband Commission for Digital Development, United Nations Educational, Scientific and Cultural Organization (UNESCO). (2013). The state of broadband 2013: Universalizing broadband. Retrieved October 19, 2013 from United Nations website: http://www.broadbandcommission.org/documents/bb-annualreport2013.pdf 
University of Calgary - Qatar. (2013). UCQ nursing portal: Nursing resources. Mobile Devices/ Smartphones. Retrieved October 19, 2013 from http://www.qatar.ucalgary.ca/learningcommons/portal 


\section{IPADS IN THE CLASSROOM: TRIALS IN A TECHNICAL COLLEGE IN QATAR}

\section{Appendix A: CNAQ pre-term technology use survey}

Directions: This survey is to find out how you use technology.

Nothing you say will change your mark. Your teacher will not know what you say until after the end of the course. We will match this survey with your course records.

Researchers will know who you are but all information shared later will not have your name on it.

You need about 15-20 minutes to do this survey. Thank you!

Section A: Technology Ownership

IMPORTANT:

These questions do not include the CNAQ iPad.

Please tell us only about any iPadyou used before the CNAQ iPad.

A1

Do you own a...

Check 田四 all

\begin{tabular}{|l|l|l|}
\hline Yes & No & $\begin{array}{l}\text { Do not } \\
\text { know }\end{array}$ \\
\hline & & \\
\hline & & \\
\hline & & \\
\hline & & \\
\hline
\end{tabular}

A. desktop computer

B. laptop computer

C. mobile phone with Internet

D. mobile computing device (netbook, iPad, Kindle, etc.)

Check $\square$ one only
A. desktop
B. laptop
C. I use both equally
D. I do not own a computer 


\section{IPADS IN THE CLASSROOM: TRIALS IN A TECHNICAL COLLEGE IN QATAR}

Which type of software is on your mobile phone?

Note: if you own more than one, please answer for the phone you use the most.

Check $\square$ one only
A. Apple (iPhone)
B. Blackberry
C. a mobile that has an Android operating system
D. other [Please explain]
E. I do not own a phone with Internet

Which do you own?

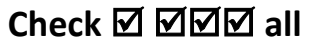
A. netbook
B. iPad
C. Kindle
D. Nook
E. other [Please explain]
F. I do not own a mobile computing device

Which is the most important to your daily life? $\square$
A. desktop computer
B. laptop computer
C. mobile phone
D. mobile computer device
E. other [Please specify]
F. don't know 
IPADS IN THE CLASSROOM: TRIALS IN A TECHNICAL COLLEGE IN QATAR

When thinking about college, which is most important to you? $\square$
A. desktop computer
B. laptop computer
C. mobile phone
D. mobile computer device
E. other [Please specify]
F. don't know

A7 Why? 


\section{IPADS IN THE CLASSROOM: TRIALS IN A TECHNICAL COLLEGE IN QATAR}

\section{Section B: Technology Use}

The questions below are about what you do every day. Before each question is a description of what is meant by each use of technology. If you do not understand please ask for help.

Study Definition: study and learning purposes

- Word, Excel, PowerPoint

- library search

- Internet to access materials and information online.

B1 During a college year, I use the technology above for study purposes...

\section{Check $\square$ one only}

$$
\begin{array}{|l|}
\hline \\
\hline
\end{array}
$$
A. every day
B. one time a week
C. less than one time a week
D. never
X. don't know

B1a Which do you use most for study purposes? $\square$

[If you answered $A, B$, or $C$ to the question above, please answer this question]

\begin{tabular}{|l|l} 
A. desktop computer \\
B. laptop computer \\
C. mobile phone \\
D. mobile computing device \\
E. other [Please specify]
\end{tabular}


Communication Definition: written and voice communication, for example:

- Skype

- email

- text messaging

- Facebook [to get or give news]

B2 During a college year, I use technology for communication... $\square$

$\square$

A. every day

B. one time a week

C. less than one time a week

D. never

X. don't know

B2a Which do you use most for communication?

[If you answered A, B, or C to the question above, please answer this question] $\square$

$$
\square
$$

A. desktop computer

B. laptop computer

C. mobile phone

D. mobile computing device

E. other [Please specify]

Entertainment Definition: for the purposes of entertainment, for example:

- online games

- YouTube, Vimeo

- Facebook [for fun] 


\section{IPADS IN THE CLASSROOM: TRIALS IN A TECHNICAL COLLEGE IN QATAR}

\begin{tabular}{|l|l} 
A. every day \\
B. one time a week \\
C. less than one time a week \\
D. never \\
X. don't know
\end{tabular}

Which do you use the most for entertainment?

[If you answered A, B, or C to the question above, please answer this question] $\square$

$$
\square
$$

A. desktop computer

B. laptop computer

C. mobile phone

D. mobile computing device

E. television

F. gaming or game devices [e.g. Xbox]

G. other [Please specify]

Information Gathering Definition (Web-browsing): to get information, for example:

- to get news (Al Jazeera, CNN, Gulf News, Al Arabiya, New York Times)

- online shopping (clothing, textbooks)

- to find information (prices, store opening times, restaurant reviews or directions)

B4 During a college year, I use technology to get information...
A. every day
B. one time a week
C. less than one time a week
D. never
X. don't know 


\section{IPADS IN THE CLASSROOM: TRIALS IN A TECHNICAL COLLEGE IN QATAR}

Which do you use most to get information?

[If you answered A, B, or C to B.5, please answer this question] $\square$

$$
\square
$$

A. desktop computer

B. laptop computer

C. mobile phone

D. mobile computing device

E. other [Please specify]

B5 I feel I accomplish [am able to do] more in my student life because of technology. $\square$
A. strongly agree
B. agree
C. neither agree nor disagree
D. disagree
E. strongly disagree

B6 If I don't use technology for a week, I feel angry or upset. $\square$
A. strongly agree
B. agree
C. neither agree nor disagree
D. disagree
E. strongly disagree

B7 On average I feel I am a/an technology user: $\square$
A. expert
B. advanced
C. intermediate
D. basic
E. non-technology 
IPADS IN THE CLASSROOM: TRIALS IN A TECHNICAL COLLEGE IN QATAR

Section C: Personal Information

C1 Name [first name + last name - e.g. Mohammed Al Marri]

$\mathrm{C} 2$

Age:

C4 Gender $\square$

\begin{tabular}{|l|l}
\hline A. & Male \\
\hline B. & Female \\
C. & Unknown
\end{tabular}

C3 Teacher of this class:

C5 What is your nationality? $\square$

A. Qatari

B. Other:

C7 Can you program in one or more computer languages [e.g. C, C++]? $\square$

A. yes

B. no

$\mathrm{C} 8$

Do you have wireless Internet at home? $\square$

A. yes

B. no

C. don't know 
IPADS IN THE CLASSROOM: TRIALS IN A TECHNICAL COLLEGE IN QATAR

C11 How many years, in total, have you been at CNAQ? $\square$

\begin{tabular}{|l|l|}
\hline A. new to CNAQ this semester \\
B. less than 1 year \\
C. 1 year \\
D. 2 years \\
E. 3 years \\
F. 4 years \\
G. 5 years or more
\end{tabular}


IPADS IN THE CLASSROOM: TRIALS IN A TECHNICAL COLLEGE IN QATAR

\section{Appendix B: Classroom observation form}

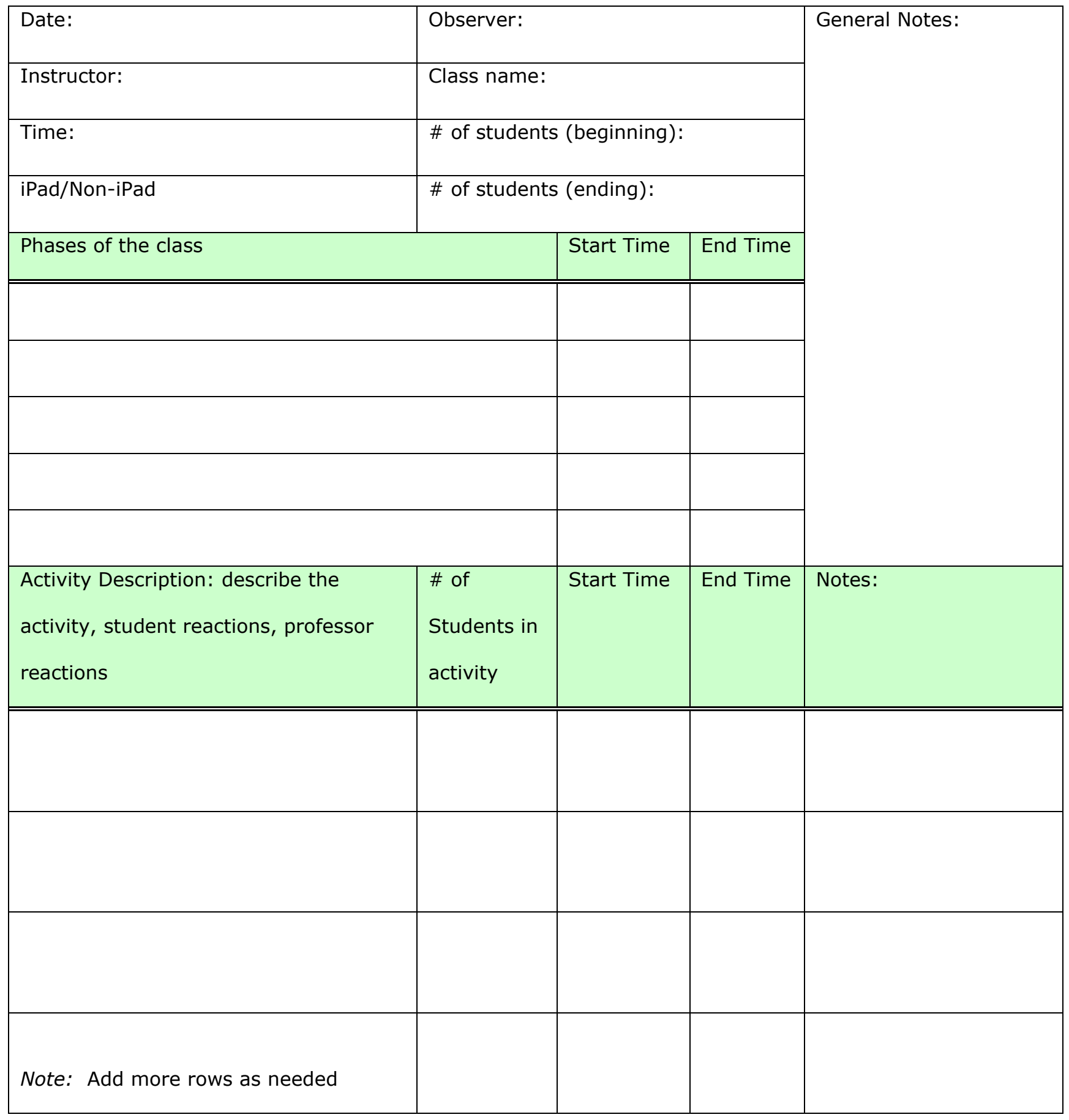




\section{IPADS IN THE CLASSROOM: TRIALS IN A TECHNICAL COLLEGE IN QATAR}

\section{Appendix C: Technology follow-up survey}

Directions: This survey is a follow-up to the technology use survey completed at the beginning of the term. It will help us to understand how the iPad was used over the term.

We need information so that we can compare this with your other study records throughout the course. Your answers will not affect grades and will not be shared with your instructor until after the term is over. The information will be known to researchers only. Any information shared with the public will have no identifying information.

This survey should take about 15 minutes to complete. Thank you for your help!

Section A: Technology Specific Questions

1. What other devices (not including the iPad) did you use during class for this course?

[Check all that apply]

A. laptop computer

B. mobile phones

C. calculator

D. tablet (Galaxy Tab, Note, Nexus10,...)

E. desktop computer (in a computer lab)

2. How often did you use other devices (not including the iPad) during class for this course?

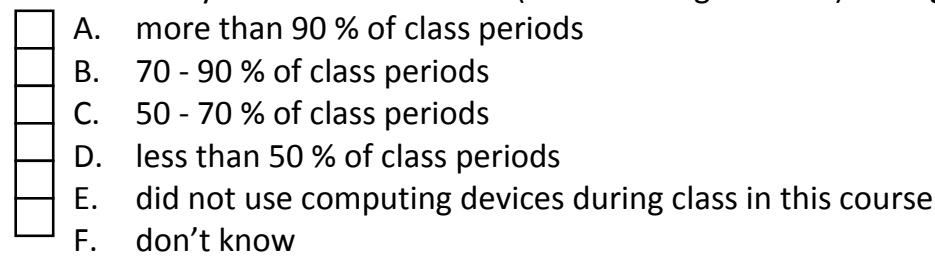

3. How did you use your devices (not including the iPad) during class for this course?

\section{[Check all that apply]}

$\square$ A. read

B. took notes

C. researched information on the Internet

D. did homework, quizzes, tests

E. presented materials to the class

F. showed information to one or more classmates

G. non-course related activities

H. other [Please specify] 


\section{IPADS IN THE CLASSROOM: TRIALS IN A TECHNICAL COLLEGE IN QATAR}

4. What other devices (not including the iPad) did you use outside of class for this course?

$\square$ A. laptop computer

B. mobile phones

C. calculator

D. tablet (Galaxy Tab, Note, Nexus10,...)

E. desktop computer in a computer lab or at home

5. How often did you use these devices (not including the iPad) outside of class for this course?

A. more than $90 \%$ of class periods

B. $70-90 \%$ of class periods

C. $50-70 \%$ of class periods

D. less than $50 \%$ of class periods

E. did not use these devices outside of class for this course

F. don't know

6 How did you use other devices (not including the iPad) outside of class for this course?

\section{[Check all that apply]}

A. read

B. took notes

C. researched information on the Internet

D. did homework, quizzes, tests

E. presented materials to the class

F. showed information to one or more classmates

G. non-course related activities

H. other [Please specify]

7. In general, do you feel your use of other devices (not including the iPad) helped you to learn material for this course?
A. yes
B. no
C. maybe
D. don't know 


\section{IPADS IN THE CLASSROOM: TRIALS IN A TECHNICAL COLLEGE IN QATAR}

\section{Section B: iPad Specific Questions}

1. How often did you use the iPad during class for this course?

$\square$ A. more than $90 \%$ of the class periods

B. $70-90 \%$ of class periods

C. $50-70 \%$ of class periods

D. less than $50 \%$ of class periods

E. don't know

2. How did you use the iPad during class for this course? [Check all that apply]

A. read materials on the iPad

B. took notes

C. researched information on the Internet

D. did homework, quizzes, tests

E. presented materials to the class

F. showed information to one or more classmates

G. non-course related activities

H. other [Please specify]

3. How often did you use the iPad outside of class for this course?

$\square$ A. more than $90 \%$ of the time

B. $70-90 \%$ of the time

C. $50-70 \%$ of the time

D. less than $50 \%$ of the time

E. did not use iPad outside of class for this course

F. don't know

4. How did you use the iPad outside of class for this course? [Check all that apply]

A. read materials on the iPad

B. took notes

C. researched information on the Internet

D. did homework, quizzes, tests

E. presented materials to the class

F. showed information to one or more classmates

G. non-course related activities

H. other [Please specify]

5. In general, do you feel your use of the iPad helped you learn material for this course?

$\square \begin{aligned} & \text { A. yes } \\ & \text { B. no } \\ & \text { C. maybe } \\ & \text { D. don't know }\end{aligned}$


6. How helpful was the iPad in the following situations: [Check one box for each]

\begin{tabular}{|c|c|c|c|c|c|c|}
\hline & $\begin{array}{c}\begin{array}{c}\text { Very } \\
\text { helpful }\end{array} \\
+2\end{array}$ & $\begin{array}{c}\text { Slightly } \\
\text { helpful } \\
+1\end{array}$ & $\begin{array}{c}\text { Neutral } \\
0\end{array}$ & $\begin{array}{c}\text { Slightly } \\
\text { unhelpful } \\
-1\end{array}$ & 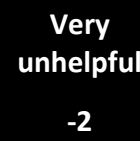 & $\begin{array}{c}\text { Not } \\
\text { Applicable }\end{array}$ \\
\hline $\begin{array}{l}\text { For use during grc } \\
\text { work }\end{array}$ & & & & & & \\
\hline $\begin{array}{l}\text { For learning new } \\
\text { things }\end{array}$ & & & & & & \\
\hline $\begin{array}{l}\text { For learning the } \\
\text { course material }\end{array}$ & & & & & & \\
\hline $\begin{array}{l}\text { For exploring } \\
\text { additional materi } \\
\text { related to the top }\end{array}$ & & & & & & \\
\hline $\begin{array}{l}\text { For getting course } \\
\text { information }\end{array}$ & & & & & & \\
\hline $\begin{array}{l}\text { For sharing } \\
\text { information with } \\
\text { others in class }\end{array}$ & & & & & & \\
\hline
\end{tabular}

7. How often did you use each of these iPad apps? [Check one box for each]

\begin{tabular}{|l|l|l|l|}
\hline \multicolumn{3}{|c|}{$\begin{array}{l}\text { More than one One time a One time during Never } \\
\text { time a week } \\
\text { week }\end{array}$} \\
\begin{tabular}{|l|l|l|l|}
\hline Google+ & $\begin{array}{l}\text { These apps were for the Mathematics class. Apps were } \\
\text { changed appropriately for the Physics class survey. }\end{array}$ \\
\hline Socrative & Air Chalk Lite & $\begin{array}{l}\text { Other applications: } \\
\text { (please list here) }\end{array}$ & \\
\hline Doceri
\end{tabular} & \\
\hline
\end{tabular}


8. Did you find other iPad apps to be helpful for this course that were not required? Please list and describe.

9. How well did you learn to use each of these iPad apps and their features? [Check one box for each]

\begin{tabular}{|c|c|c|c|c|c|c|c|c|}
\hline & Expert & $\begin{array}{l}\text { Very } \\
\text { good }\end{array}$ & Good & Neutral & Poor & $\begin{array}{l}\text { Very } \\
\text { poor }\end{array}$ & $\begin{array}{l}\text { Didn } \\
\text { use } \\
\text { app }\end{array}$ & $\begin{array}{l}\text { 'th } \\
\text { this }\end{array}$ \\
\hline Google+ & \multirow{5}{*}{\multicolumn{7}{|c|}{$\begin{array}{l}\text { These apps were for the Mathematics class. Apps were } \\
\text { changed appropriately for the Physics class survey. }\end{array}$}} & \\
\hline Socrative & & & & & & & & \\
\hline Air Chalk Lite & & & & & & & & \\
\hline Doceri & & & & & & & & \\
\hline $\begin{array}{l}\text { Other applications: } \\
\text { (please list here) }\end{array}$ & & & & & & & & \\
\hline
\end{tabular}

10. I believe that using the iPad in class helped me to interact more with my classmates.
A. Strongly agree
B. Agree
C. Neither agree nor disagree
D. Disagree
E. Strongly disagree

11. I believe that using the iPad in class helped me to interact more with online course materials for my class.
A. Strongly agree
B. Agree
C. Neither agree nor disagree
D. Disagree
E. Strongly disagree 


\section{IPADS IN THE CLASSROOM: TRIALS IN A TECHNICAL COLLEGE IN QATAR}

12. In the table below, mark the box for the apps that apply for each column. [If applicable, check more than one box for each app.]

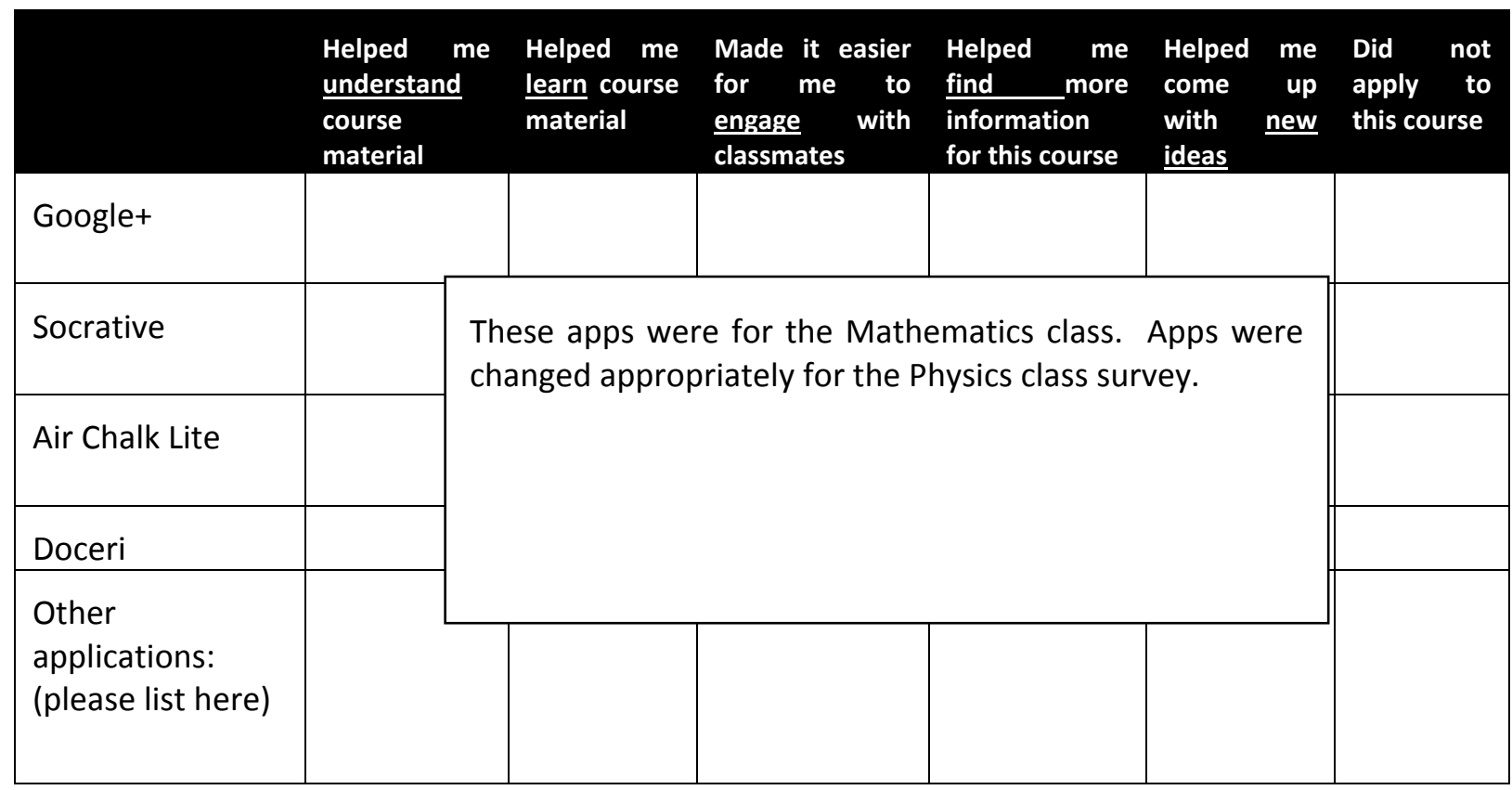

13. In general, do you feel the iPad for this course was useful?

$\square \begin{array}{ll}\text { A. } & \text { yes } \\ \text { B. } & \text { no } \\ \text { C. } & \text { maybe } \\ \text { D. } & \text { don't know }\end{array}$

14. Please give 1 example of the iPad when it helped you in this course.

15. Please give 1 example of the iPad when it did not help you in this course. 


\section{IPADS IN THE CLASSROOM: TRIALS IN A TECHNICAL COLLEGE IN QATAR}

\section{Section C: Technology Use Questions}

1. Overall, technology makes my life easier.
A. strongly agree
B. agree
C. neither agree nor disagree
D. disagree
E. strongly disagree

2. I feel I can do more in my student life because of technology.

\begin{tabular}{|l} 
A. \\
B. agrongly agree \\
C. neither agree nor disagree \\
D. disagree \\
E. strongly disagree
\end{tabular}

3. If I don't use technology for a week, I feel unhappy.
A. strongly agree
B. agree
C. neither agree nor disagree
D. disagree
E. strongly disagree

4. On average I feel I am a(n) with the technologies I use.

\begin{tabular}{|l} 
\\
$\begin{array}{l}\text { A. } \\
\text { B. }\end{array}$ advanced user \\
C. intermediate user \\
D. basic user \\
E. non-technology user
\end{tabular}




\section{IPADS IN THE CLASSROOM: TRIALS IN A TECHNICAL COLLEGE IN QATAR}

Section D: Personal Information

1. Please print your first and last name on the line below.

First Name Last Name

2. Student ID number.

3. Your Age.

4. What is your gender?

A. Male

B. Female

C. Unknown 